Kazimierz Butelski (k.butelski@pk.edu.pl)

Magdalena Kozień-Woźniak (mkozien@pk.edu.pl)

Marta Łukasik (marta.lukasik@pk.edu.pl)

\title{
Architektura jako narzędzie rozwiązywania wybranych problemów społecznych - na przykładzie Leżajska, Niepołomic i Wieliczki
}

\section{Architecture as a tool for solving selected social problems - on the examples of Leżajsk, Niepołomice and Wieliczka}

\begin{abstract}
Streszczenie
Realizowana w Pracowni Architektury Społeczno-Usługowej od lat metoda dydaktyczna polega na opracowywaniu projektów studialnych w małych miastach w celu zapoznania studentów ze specyfiką wprowadzania nowych form architektonicznych w zastane środowisko kulturowe. Cenne jest przy realizacji tego zadania nawiązywanie współpracy ze społecznościami lokalnymi i współpraca przy realizacji projektu - od sformułowania wytycznych projektowych i zaproponowania lokalizacji dla wybranego tematu, aż po organizację wystawy i ocenę przedstawionych przez studentów propozycji projektowych. Te studialne prace mogą mieć znaczenie przy podejmowaniu w przyszłości decyzji lokalizacji obiektów użyteczności publicznej i ich wpływu na strukturę przestrzenną miasta, a także sprzyjać zrównoważonemu rozwojowi i wzmocnieniu potencjału ekonomicznego. Dotychczas nawiązano współpracę i realizowano projekty z przedstawicielami Leżajska, Niepołomic oraz Wieliczki.
\end{abstract}

Słowa kluczowe: Leżajsk, chasydzi, Instytut Judaistyki Uniwersytetu Jagiellońskiego, opieka, seniorzy, juniorzy, Laboratorium Akustyki Technicznej AGH

\begin{abstract}
The methodology taught from years in the Chair of Social and Public Building Design has been invented to develop study projects in small towns to familiarize students with the specificity of introducing new architectural forms into the existing cultural environment. It is extremely valuable to cooperate with local communities and to work together during this project - formulation of design guidelines and proposing locations for the chosen topic, up to the organization of the exhibition and evaluation of the students design proposals. These studies may have gave an important implications for the city in future decisions regarding the location of public buildings and their impact on the spatial structure. They can also foster the sustainable development and strengthening the economic potential. So far, cooperation has been established with such cities as Leżajsk, Niepołomice and Wieliczka.
\end{abstract}

Keywords: Leżajsk, Chasidic, Institute of Judaic Studies, Jagiellonian University, careers, seniors, juniors, Laboratory of Technical Acoustics AGH 


\section{LEŻAJSK ELIMELECHA - MUZEUM CHASYDÓW POLSKICH}

Wierząc, że architektura może służyć rozwiązywaniu problemów społecznych, przeprowadziliśmy w naszym zespole dydaktycznym projekt poświęcony Leżajskowi i chasydom.

Do tego położonego w województwie podkarpackim miasta przyjeżdża corocznie kilkanaście tysięcy chasydów z całego świata, zwłaszcza w rocznicę śmierci cadyka Elimelecha, którego grób się tam znajduje. Wraz z ich przybyciem miasto na kilka dni zmienia swój charakter, słychać śpiew i widać tańce tysięcy tradycyjnie ubranych chasydów. Elimelech to charyzmatyczny mistyk działający w Leżajsku, który jest ostatnim uznawanym przez wszystkie odłamy chasydyzmu przywódcą duchowym. Od czasów Holocaustu w Leżajsku nie ma już chasydów, przedstawicieli ruchu religijnego w obrębie judaizmu, powstałego na ziemiach polskich w okresie wojen polsko-tureckich ${ }^{1}$. W okresie swojego powstania chasydyzm był niezwykle progresywny w stosunku do dotychczasowej tradycyjnej religii żydowskiej, co objawiało się manifestowaniem swojej religijności przez śpiew i taniec oraz transową modlitwę. Z biegiem czasu został on zaakceptowany przez innych przywódców religijnych i dzisiaj stanowi najbardziej tradycyjny i konserwatywny nurt judaizmu. W okresie międzywojennym chasydyzm był silnie krytykowany przez progresywistyczne środowiska żydowskie z Europy Zachodniej i utożsamiany z Żydami zamieszkującymi wschodnią Europę.

Leżajsk był kiedyś wielokulturowym miastem, w którym współżyły trzy główne narodowości: Polacy, Rusini i Żydzi. Od czasów II wojny światowej sytuacja ta uległa zmianie i jest zamieszkiwany obecnie przede wszystkim przez Polaków. Przybycie chasydów na uroczystości rocznicowe przywraca więc na chwilę historyczną strukturę społeczną miasta. Holocaust to jednak nie tylko proces unicestwienia narodu, ale również śladów kultury materialnej z nim związanych, w tym miejsc kultu religijnego, cmentarzy i budynków społecznych. To wymazywanie pamięci ma też inny wymiar i odbywa się przez podmianę wartości. Tam, gdzie struktury materialnej nie udało się zniszczyć i unicestwić, wprowadzono nowe, inne od pierwotnych funkcje. Ślady wielokulturowości miasta są jednak ciągle obecne, zwłaszcza w jego strukturze urbanistycznej. W miejscu, gdzie znajdował się cmentarz żydowski, ciągle ogrodzony murem, przetrwało kilka nagrobków i odbudowany murowany grób Elimelecha, nazywany Ohel ${ }^{2}$, co w języku żydowskim oznacza namiot.

Współcześnie Leżajsk w okresie rocznicy też pokryty jest kilkoma wielkogabarytowymi namiotami, specjalnie postawionymi na tę okazję. Ponadto, aby przyjąć pielgrzymujących i zapewnić im możliwość noclegów i posiłków, wynajmuje się szkoły i restauracje zlokalizowane w Leżajsku.

Tymczasowość struktur i miejsc, symbolizowana przez namiot, jest jednym z istotnych do rozstrzygnięcia problemów projektowych. Historycznie kultura żydowska wywodzi się z Bliskiego Wschodu i związana jest z kulturą koczowniczą, w której namiot jako forma tymczasowa doskonale spełniał swą funkcję. Z drugiej jednak strony rozwój cywilizacji sprzyjał budowaniu stałych siedzib o cechach trwałości. Trwaniu stabilności i niezmienności 
często nadawano wymiar symboliczny, czego dobrym przykładem jest słynna jerozolimska Ściana Płaczu. Kierunkiem rozwoju cywilizacji jest zatem budowanie trwałości związanej z poczuciem stabilizacji i bezpieczeństwa.

W projekcie tym przyświecała nam też idea propagowana przez prof. Bulińskiego, który uważa, że budynki powinny być budowane jako świadectwo czasów, w jakich powstają, i w żadnym razie nie powinny być kopiami historycznych rozwiązań. Zakładaliśmy zatem, że będą to rozwiązania cechujące się inwencją i nowatorstwem. Jednocześnie jednak musieliśmy mieć na uwadze konserwatywną naturę współczesnego chasydyzmu oraz cechującą ten ruch religijny swoistą introwertyczność wobec świata zewnętrznego.

W Leżajsku społeczność żydowska posiada w pobliżu grobu Elimelecha nieruchomości, jednak ich struktura przestrzenna i stan techniczny nie odpowiadały potrzebom, stąd zaplanowano budowę centrum kultury. Na tym tle powstały nieporozumienia i wzajemne pretensje z władzami miasta, wynikające z niezrozumienia skomplikowanej procedury administracyjnej związanej z uzyskiwaniem pozwoleń urbanistycznych i decyzji o pozwoleniu na budowę. Projekt samej inwestycji nie był również publicznie znany, co w społeczności lokalnej budziło różnorodne spekulacje. W efekcie, przystępując do projektu studialnego, spotkaliśmy się z dużą rezerwą z obu stron i nawet początkowo odmówiono nam udostępnienia map do celów tego projektu. Od początku ideę budowy Muzeum Chasydów Polskich w Leżajsku wspierało Muzeum Ziemi Leżajskiej, a jego dyrektor Andrzej Chmura objął patronat nad tym projektem.

Przygotowując projekt w Krakowie, udało się po uzyskaniu map spotkać z naczelnym rabinem Krakowa Eliezerem Gurarym ${ }^{3}$ i ustalić z nim, czy proponowana lokalizacja w sąsiedztwie cmentarza żydowskiego w Leżajsku nie narusza jego granic, co byłoby niezgodne z regułami judaizmu, zakazującymi jakichkolwiek interwencji w jego obrębie. Co ciekawe, pierwszy raz w historii Krakowa w okresie realizacji naszego projektu naczelnym rabinem został chasyd.

Nieoceniony wkład w przygotowanie merytorycznego projektu i budowę odpowiedniego programu oraz konstruktywną krytykę miała współpraca z Instytutem Judaistyki Uniwersytetu Jagiellońskiego. Wykłady o chasydyzmie prof. Michała Galasa, kierownika Zakładu Historii Judaizmu i Literatur Żydowskich, wprowadziły nas w mistyczny świat chasydów i ich przypowieści. Doktor architekt Piotr Lewicki z Biura Projektów Lewicki Łatak podzielił się z kolei z nami swoimi doświadczeniami projektowymi, wyniesionymi z prac nad pawilonem przygotowanym na święto Sukkot. W projekcie tym nowoczesna forma korespondowała z tradycyjnym religijnym postulatem budowy obiektu upamiętniającego mieszkanie w namiotach podczas ucieczki Izraelitów z Egiptu i wędrówki do Kanaanu.

Studenci otrzymali ramowy program obiektu, który zawierał salę wielofunkcyjną, sale ekspozycyjne, bibliotekę i część hotelową oraz część gastronomiczną. Program ten mógł ulegać modyfikacjom zaproponowanym przez projektantów i miał być maksymalnie elastyczny. Głównym założeniem programowym było stworzenie całorocznego centrum, służącego zarówno chasydom odwiedzającym Leżajsk, jak i samym mieszkańcom oraz turystom. 
Nie zdefiniowano żadnej konkretnej działki przeznaczonej na ten budynek, a jedynie zdefiniowano obszar pomiędzy strukturą historycznej części miast a cmentarzem w okolicach ulicy Górnej i Dolnej. Teren ten, o zróżnicowanej morfologii, dawał różnorodne możliwości lokalizacji muzeum, których pełną paletę zobaczyliśmy w końcowej multimedialnej prezentacji każdego studenta.

Na początku jednak była praca zespołowa i budowa makiet urbanistycznych w grupach pięcioosobowych, co pozwoliło studentom dotknąć budynków, jarów i uliczek Leżajska. Równolegle z tą pracą i opisanymi powyżej wykładami prowadzili swoje własne badania nad tematyką projektu. W momencie ukończenia modelu i eseju dotyczącego swoich badań byli gotowi do dyskusji, która odbyła się na miejscu w Leżajsku. Po powrocie i weryfikacji swoich wyobrażeń ze stanem faktycznym przystąpili do opracowania swoich indywidualnych projektów. Główną strategią projektową była dyskusja o modelach indywidualnych muzeów, każdorazowo umieszczanych w modelu matce.

Końcowa prezentacja, poza częścią multimedialną, składa się z jednej planszy konkursowej, mającej przedstawić zasadniczą ideę projektową, oraz wydruku w formacie A3 rysunków wymaganych programem studiów. Na tej podstawie prace zostały ocenione przez zespół dydaktyczny według podanych wcześniej kryteriów.

Interesującym doświadczeniem, zarówno dla zespołu dydaktycznego, jak i dla studentów, był konkurs i ocena niezależnego jury w składzie: przewodniczący Andrzej Chmura - dyrektor Muzeum Ziemi Leżajskiej, dr hab. Michał Galas - kierownik Zakładu Historii Judaizmu i Literatur Żydowskich w Instytucie Judaistyki Uniwersytetu Jagiellońskiego, dr inż. arch. Piotr Lewicki - architekt z Biura Projektów Lewicki Łatak oraz dr inż. arch. Rafał Zawisza - prodziekan Wydziału Architektury Politechniki Krakowskiej, które dokonało oceny prac i przyznało na uroczystej gali sześć wyróżnień oraz trzy nagrody główne dla projektów:

I nagroda: Adam Łyko,

II nagroda: Piotr Łatak,

III nagroda: Iwona Pawlak i III nagroda równorzędna: Damian Strug.

Wszystkie nagrodzone i wyróżnione prace prezentowały wysoki poziom merytoryczny i były zasadniczo zgodne z wcześniejszą wewnętrzną oceną zespołu dydaktycznego, który jedynie w detalach rozkładał inaczej akcenty.

Otwarcie wystawy w Muzeum Ziemi Leżajskiej uświetnił swoją obecnością prezydent miasta Leżajska oraz główny architekt miasta. Fakt ten wskazuje na to, iż projekt spełnił swe założenie, ponieważ od początkowego dystansu do tej idei dokonał się zasadniczy zwrot ku jej poparciu, wyrażony żywym zainteresowaniem studenckimi propozycjami. Miasto ma bowiem obecnie do zaoferowania potencjalnym inwestorom kilkadziesiąt projektów różnych rozwiązań zarówno formalnych, jak i urbanistycznych. 
Za sukces należy także uznać kontynuację tej wystawy w Krakowie w Żydowskim Muzeum Galicja między 10 marca a 30 kwietnia 2015 roku. Otwarciu krakowskiej wystawy towarzyszyła dyskusja na temat: „Nie tylko pamięć - architektura żydowska we współczesnej Polsce”. W debacie udział wzięli: dr hab. Michał Galas z Instytutu Judaistyki Uniwersytetu Jagiellońskiego oraz dr hab. inż. arch. Kazimierz Butelski oraz dr inż. arch. Magdalena Kozień-Woźniak z Pracowni Architektury Społeczno-Usługowej Wydziału Architektury Politechniki Krakowskiej. Dyskusję prowadziła dr Edyta Gawron z Instytutu Judaistyki Uniwersytetu Jagiellońskiego.

\section{MŁODOŚĆ I STAROŚĆ W ARCHITEKTURZE - DOM SENIORA I DOM JUNIORA W NIEPOŁOMICACH}

Studenci siódmego semestru pierwszego stopnia Wydziału Architektury Politechniki Krakowskiej otrzymali zadanie próby rozwiązania problemów społecznych osób starszych oraz porzuconych małych dzieci za pomocą interwencji architektonicznej. Projekty były realizowane w semestrze zimowym roku akademickiego 2015/2016 w Pracowni Architektury Społeczno-Usługowej, pod kierownictwem dr. hab. inż. arch. Kazimierza Butelskiego, prof. PK. Zajęcia prowadzone były w grupach dr. hab. inż. arch. Kazimierza Butelskiego, prof. PK, dr hab. inż. arch. Magdaleny Kozień-Woźniak oraz mgr inż. arch. Marty Łukasik.

W związku ze zjawiskiem starzenia się populacji, które możemy zaobserwować nie tylko w Polsce, ale i na całym świecie, pojawia się potrzeba odnalezienia odpowiedzi na zadany problem społeczny. Zadaniem studentów było zaprojektowanie Domu Seniora. Aby zapoznać się z tematyką domu spokojnej starości, zorganizowana została wizyta w Domu Helclów - krakowskim przykładzie miejsca opieki dla osób starszych. Należało wymyślić strukturę mogącą tworzyć przestrzeń do życia, przez co należy rozumieć strefę mieszkalną, wzbogaconą o miejsce do wypoczynku i rekreacji. Budynek miał również zapewnić rezydentom strefę opieki medycznej oraz zaplecze dla pracowników i administracji, a także niezbędną część gospodarczo-techniczną. Funkcję uzupełniającą w budynku stanowiła kaplica.

Z kwestią dotyczącą schyłku życia człowieka zestawiono temat małych, osieroconych dzieci. Ćwiczeniem projektowym była placówka opiekuńczo-wychowawcza, której celem byłoby zapewnienie całodobowej opieki i wychowania dzieciom od urodzenia do 3 lat, które częściowo lub całkowicie zostały pozbawione opieki rodziców lub opiekunów. Najczęściej dzieci umieszczane są w tego typu ośrodkach w wyniku interwencji policji, na podstawie postanowień sądu, ale również na prośbę rodziców, będących chwilowo w trudnej sytuacji życiowej i potrzebujących wsparcia. Obiekt taki docelowo zatrudniałby personel, który zajmuje się codzienną pielęgnacją małego dziecka, wychowaniem, diagnozowaniem stanu zdrowia i poziomu rozwoju, a w przypadku wykrycia nieprawidłowości podjęciem leczenia i rehabilitacją. Wiedząc, jak bardzo ważne są pierwsze lata życia dziecka, miejsce takie w naszej sugestii nie opierałoby się wyłącznie na zaspokajaniu podstawowych potrzeb dzieci. Dzięki odpowiednim 
rozwiązaniom architektonicznym można stworzyć warunki do prawidłowego rozwoju fizycznego, psychicznego i umysłowego. Dom ten w swoim założeniu przeznaczony byłby dla 80 małych wychowanków. Wielospecjalistyczną opiekę zapewnialiby m.in. wychowawcy, psychologowie, lekarze, pielęgniarki i położne, rehabilitant, logopeda i pracownik socjalny.

Studenci mieli możliwość wyboru tematu spośród dwóch omówionych powyżej i zaprojektowania obiektu na zadanej działce. Problemem projektowym było z jednej strony znalezienie form przestrzennych dla wybranego zagadnienia, z drugiej natomiast zaprojektowanie wielofunkcyjnej przestrzeni, która w ciągu roku będzie mieć zastosowanie także na potrzeby lokalnej społeczności wybranego miasta.

Jako lokalizację zamierzenia wyznaczono Niepołomice, które dzięki swojej odległości od Krakowa stanowią zdaniem prowadzących przedmiot właściwe miejsce dla nowo projektowanego obiektu. Wybrana działka o powierzchni $4000 \mathrm{~m}^{2}$ znajduje się w posiadaniu parafii rzymskokatolickiej im. Dziesięciu Tysięcy Męczenników. Na jej terenie znajduje się obecnie parking, a pozostałą jej część stanowi niezagospodarowany obszar zielony. Dzięki uprzejmości władz miasta udostępniony został podkład w formie mapy sytuacyjno-wysokościowej. Proces projektowy poprzedzony został przez analizę struktury przestrzennej i wizję lokalną. Dokumentacja fotograficzna oraz empiryczne zapoznanie się z charakterem miasta pozwoliło studentom na stworzenie modeli wyznaczonego fragmentu otoczenia działki w skali 1:500. Były one podstawą do badań i studiów nad sytuacją oraz analiz przestrzennych otoczenia. Stanowiły również punkt wyjścia do własnych koncepcji projektowych, przedstawionych w początkowej fazie w formie modeli indywidualnych. Modele te były oceniane w kontekście stworzonych wcześniej „modeli matek”. Kolejnym etapem było rozwiązanie zaakceptowanej wcześniej fazy modelowej projektu w formie koncepcji rysunkowej. Do dyspozycji studenci mieli ramowe programy funkcjonalne Domu Seniora i Domu Juniora, które stanowiły element wyjściowy do rozważań przestrzennych i funkcjonalnych. Rysunkowe rozwiązania obejmowały m.in.: urbanistykę, rzuty, przekroje, elewacje i widoki perspektywiczne. Podbudową teoretyczną do projektów były przygotowane przez studentów eseje na temat „Młodość i starość w architekturze”, które prezentowały ich pomysły podejścia do zadanego problemu. Całość projektu uzupełniał opis techniczny, zawierający formę, funkcję i konstrukcję oraz rozwiązania materiałowe zaprojektowanych obiektów. Część rysunkowa była zaprezentowana przez każdego studenta również w formie planszy konkursowej.

Formy współpracy pomiędzy uczelnią a przedstawicielami władz miasta realizowane były od sformułowania wytycznych projektowych i zaproponowania lokalizacji dla wybranego tematu, aż po organizację wystawy i ocenę przedstawionych przez studentów propozycji projektowych. Otwarcie wystawy prac konkursowych w Laboratorium Aktywności Społecznej w Niepołomicach uświetnił swoją obecnością mgr inż. arch. Adam Twardowski - zastępca burmistrza miasta i gminy Niepołomice. Wernisażowi towarzyszyła dyskusja na temat kontekstu i kondycji architektury małych polskich miast. Jury w składzie: mgr inż. arch. Adam Twardowski - zastępca burmistrza miasta i gminy Niepołomice, mgr Piotr Szewczyk - dyrektor Domu Pomocy 
Społecznej i Dziennego Domu Pobytu w Staniątkach, mgr Wojciech Biernat - kierownik Referatu Strategii i Rozwoju UMiG Niepołomice, dokonało oceny prac i przyznało na uroczystej gali nagrodę główną oraz pięć wyróżnień. Najwyżej oceniony został projekt Adama Peciaka. Wyróżnienia otrzymali: Jan Janik, Katarzyna Koryga, Klaudia Lekston, Anita Nowak, Jonathan Sanchez Lopez. Publiczna prezentacja studenckich prac dała szansę na szeroką dyskusję i obserwację reakcji społecznych na zaproponowane interwencje architektoniczne. Z niecierpliwością czekamy na dalszy wpływ takich koncepcji na strategię rozwoju miasta i na możliwą implementację przeprowadzonych przez studentów wyników analiz.

Temat ten był również przedmiotem inżynierskiego projektu dyplomowego dla wybranej grupy pięciu studentów, czego efektem były ciekawe i różnorodne koncepcje architektoniczne, dopracowane w stosunku do prac kursowych między innymi o projekt wybranego fragmentu projektu w skali 1:50.

Realizowana metoda dydaktyczna polega na opracowywaniu projektów w małych miastach w celu zapoznania studentów ze specyfiką wprowadzania nowych form architektonicznych w zastane środowisko kulturowe. Stąd niezwykle cenne jest nawiązywanie współpracy uczelni ze społecznościami lokalnymi i współdziałanie przy realizacji projektu. Te studialne prace mogą mieć dla miasta znaczenie przy podejmowaniu w przyszłości decyzji o lokalizacji obiektów użyteczności publicznej i ich wpływu na strukturę przestrzenną miasta. Mogą one także sprzyjać zrównoważonemu rozwojowi i wzmocnieniu potencjału ekonomicznego miasta, pokazując możliwości, jakie niesie współczesna architektura. Dla studentów zaś nauka ta jest bezcenna, ukazując im różnorodność i bogactwo polskiej kultury.

\section{SALA KONCERTOWA W WIELICZCE}

Wejście Polski do Unii Europejskiej dało szansę rozwoju nie tylko metropolii, ale również mniejszych miast i gmin. Pierwsze były inwestycje w infrastrukturę techniczną - budowano wodociągi, kanalizację, drogi i chodniki. Następnie wznoszono przede wszystkim sale gimnastyczne i szkoły. Nadszedł też czas dla kultury. Samorządy budują biblioteki i kina.

Przygotowując temat projektowy dla studentów siódmego semestru studiów pierwszego stopnia na kierunku architektura, postanowiono przyglądnąć się Wieliczce - miastu o bogatych tradycjach, historii i strukturze przestrzennej. W ciągu ostatnich kilkunastu lat w mieście przeprowadzono wiele inwestycji infrastrukturalnych. Obecnie w swoim programie władze miasta przedstawiają propozycje projektów do poszczególnych Programów Regionalnych Województwa Małopolskiego ${ }^{4}$. Są wśród nich inwestycje takie jak: budowa dróg i połączeń odbarczających miasto Wieliczkę oraz uporządkowanie ruchu w centrum miasta, budowa kanalizacji, budowa stacji uzdatniania wody „Bogucice” wraz z ujęciami wody, budową i przebudową sieci wodociągowych wraz z infrastrukturą towarzyszącą w gminie Wieliczka. W miejscowościach gminy powstały świetlice środowiskowe. W Wieliczce wybudowano Regionalne Centrum 
Oświatowo-Sportowe oraz prowadzona jest budowa nowoczesnego kompleksu bibliotecznego wraz z salą kinową, mającego pełnić funkcję centrum kulturalnego.

Jako temat projektowy dla Wieliczki, mogący stać się kolejnym etapem w jej kulturowym rozwoju, zaproponowano salę koncertową. Pomysł został przedstawiony burmistrzowi miasta Arturowi Koziołowi oraz dyrektorce Szkoły Muzycznej I stopnia w Wieliczce Izabeli Szocie. Myśl o budowie sali koncertowej w Wieliczce spotkała się z dużym zainteresowaniem oraz pozytywną odpowiedzią na propozycję współpracy. W organizację zadania włączył się Wydział Kultury Urzędu Miasta i Gminy Wieliczka, który zaproponował przygotowanie wystawy prac studenckich w „Solnym Mieście” - Regionalnym Centrum Oświatowo-Sportowym w Wieliczce. Wystawa projektów studenckich miała w dyskusję o temacie włączyć lokalną społeczność.

Wykonanie projektu sali koncertowej w Wieliczce stało się zadaniem studentów architektury ostatniego semestru pierwszego stopnia w semestrze zimowym roku akademickiego 2016/2017. Zajęcia prowadzone były w Pracowni Architektury Społeczno-Usługowej Instytutu Projektowania Architektonicznego Wydziału Architektury Politechniki Krakowskiej. Zajęcia prowadzone były w zespole: dr hab. inż. arch. Kazimierz Butelski, dr hab. inż. arch. Magdalena Kozień-Woźniak, mgr inż. arch. Marta Łukasik, mgr inż. arch. Magdalena Zapała.

Pierwszym zadaniem studentów było wykonanie w grupach kilku „modeli matek” dla fragmentu miasta pomiędzy terenami Kopalni Soli oraz zabytkowym klasztorem reformatów. Przez budowę modeli studenci poznawali miasto, jego strukturę topograficzną, urbanistyczną i transportową. Ta część pracy konsultowana była z profesorami wizytującymi z Libanu - prof. Maroun el-Daccache i prof. Halą Younes oraz z prof. Raimundem Feinem z Niemiec. W tej części studenci przeprowadzali także studia wnętrza sali koncertowej, określali jej gabaryty i kształt oraz podstawowe założenia akustyczne, czego podsumowaniem były konsultacje specjalistyczne z zespołem prof. Tadeusza Kamisińskiego z AGH. W tej fazie studenci tworzyli robocze modele budynku sali.

Częścią procesu dydaktycznego był wyjazd studialny do Wieliczki, podczas którego studenci mieli okazję wysłuchać prezentacji na temat historii miasta oraz planach i kierunkach rozwoju Wieliczki, a pani Izabela Szota - dyrektor Szkoły Muzycznej I stopnia, wprowadziła ich w tematykę akustyki sal koncertowych i potrzeb użytkowników.

Druga faza prac projektowych dotyczyła opracowań w formie graficznej. Do dyspozycji projektanta był podkład mapowy oraz program funkcjonalno-użytkowy budynku. Każdy student zobligowany był do kompleksowego przedstawienia swojej idei projektowej w formie rzutów, przekrojów elewacji oraz wizualizacji budynku i wnętrza sali koncertowej.

Wybrane rysunki projektu studenci opracowali w formie plansz konkursowych, które zostały przekazane do Wydziału Kultury Urzędu Miasta i Gminy Wieliczka. Sąd konkursowy pod przewodnictwem burmistrza miasta Artura Kozioła wyłonił zwycięzców. Prace wystawiono w hallu głównym „Solnego Miasta” - Regionalnego Centrum Oświatowo-Sportowego w Wieliczce, gdzie mogli je oglądać mieszkańcy i goście miasta. Studialne propozycje studenckie stały się w ten sposób polem dyskusji lokalnej społeczności o możliwych kierunkach rozwoju oraz znaczeniu jakości architektonicznej w przestrzeni miasta. 


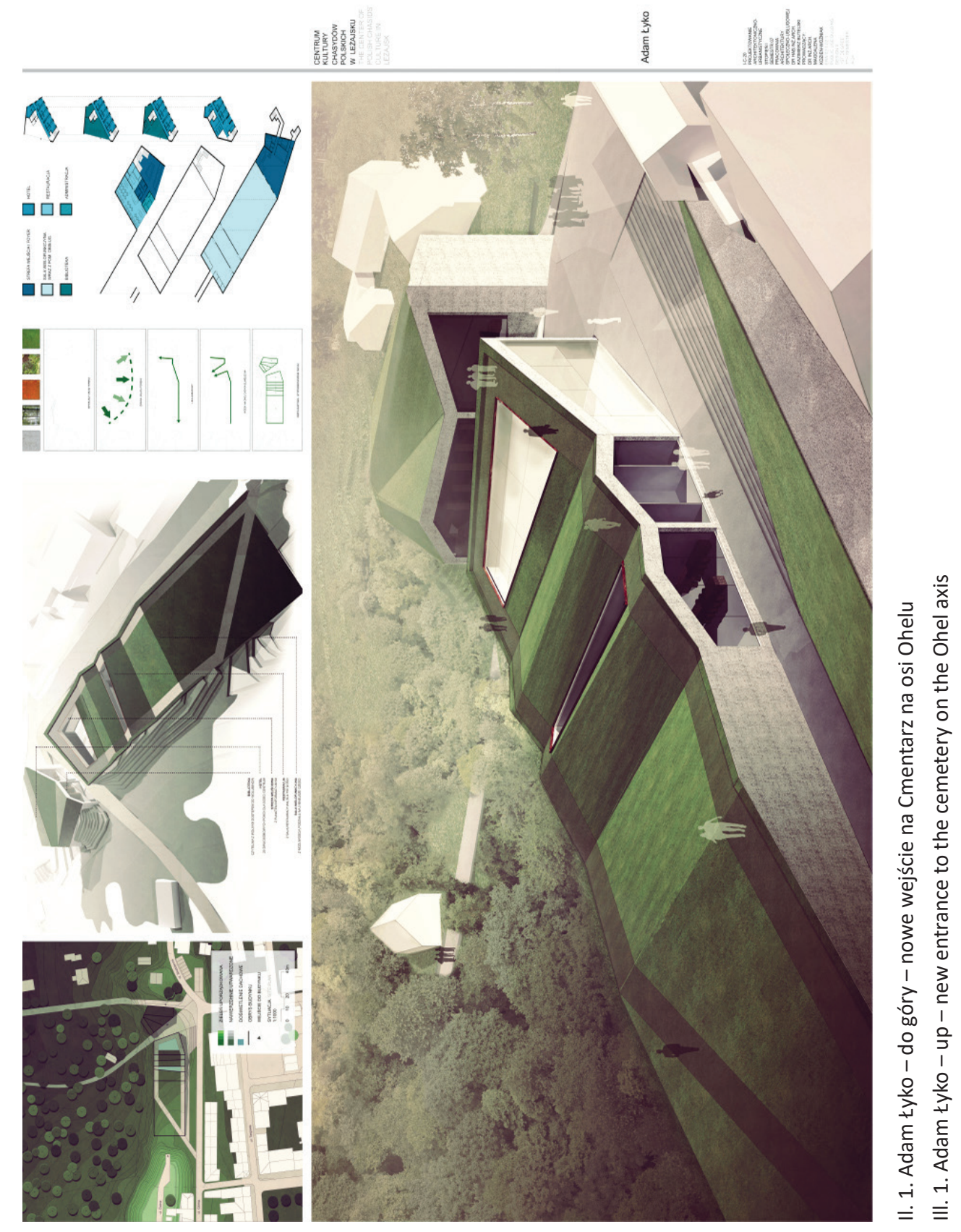



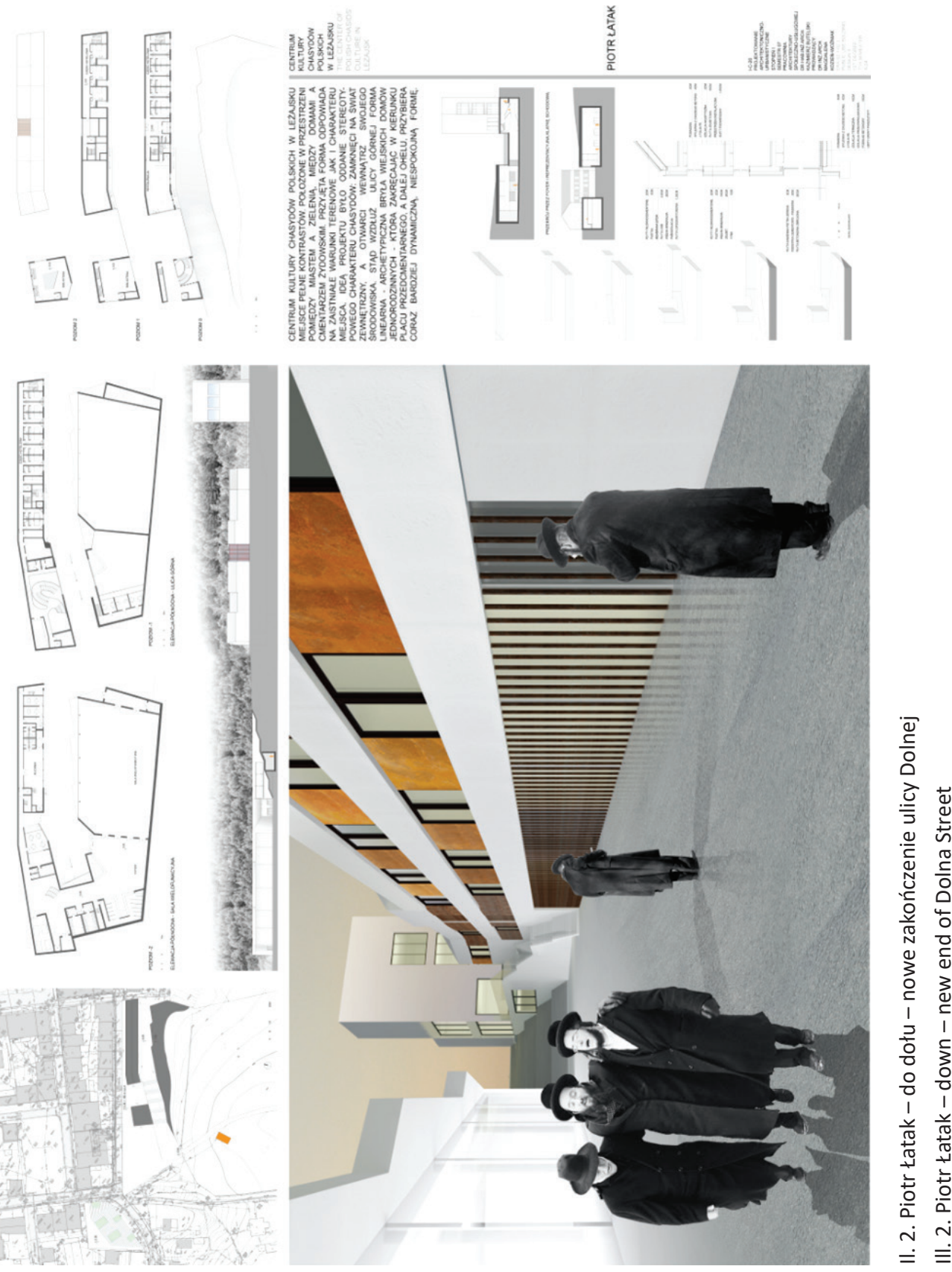

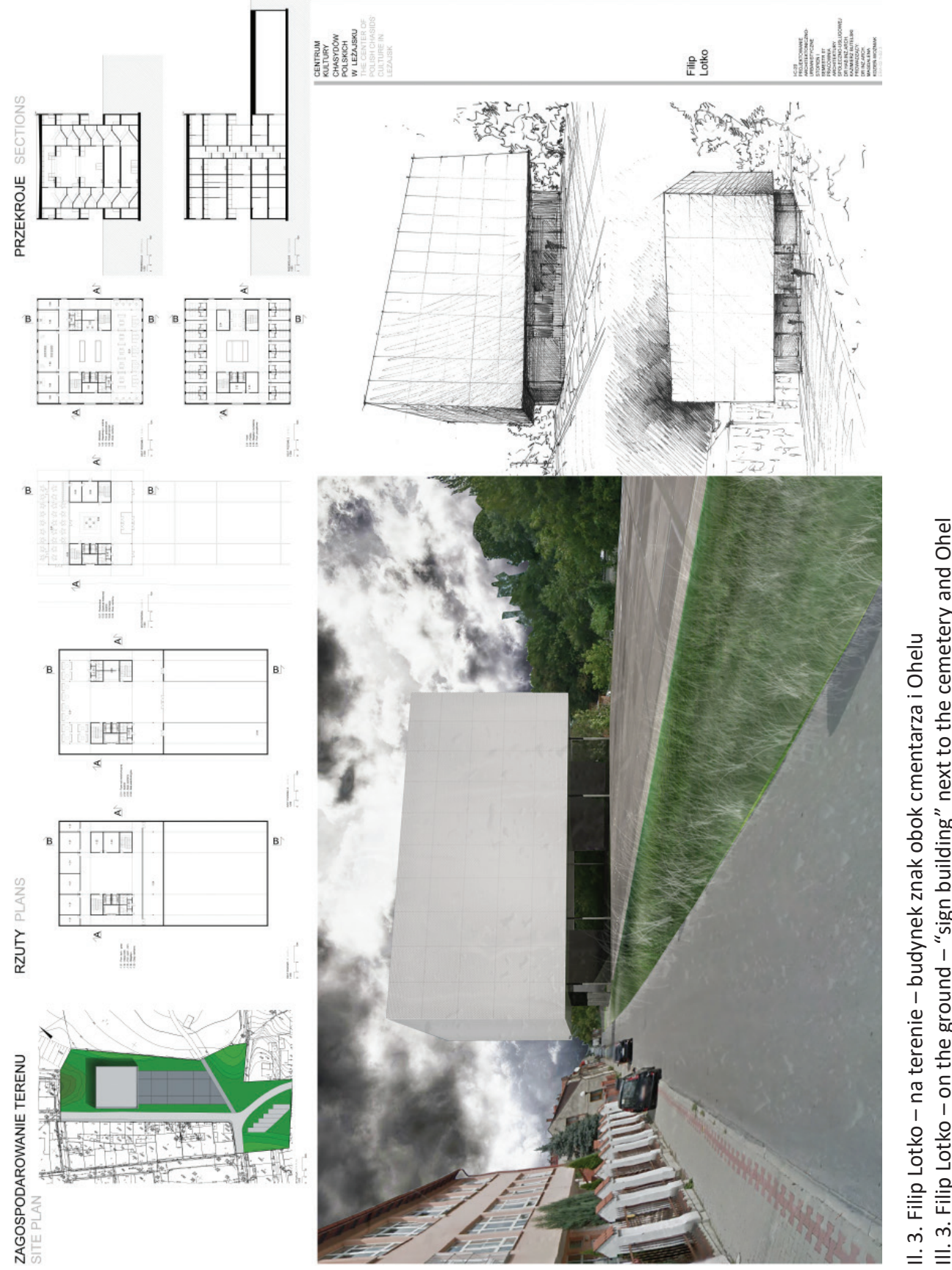


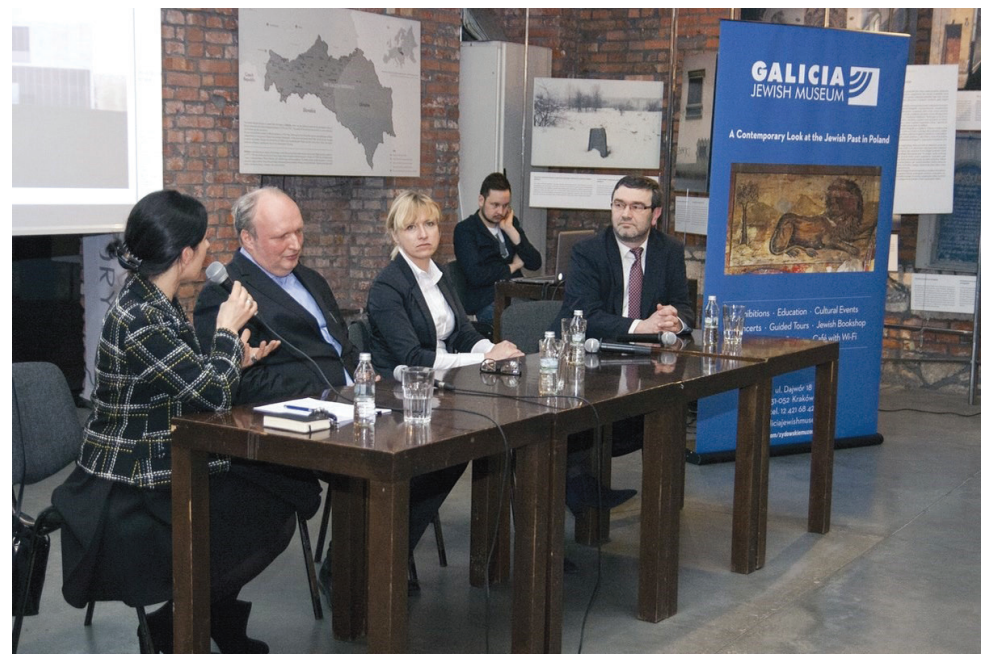

II. 4. Dyskusja w Muzeum Galicja „Nie tylko pamięć - Architektura żydowska we współczesnej Polsce” III. 4. Discussion in the Galicia Museum „Not Just Memory - Jewish Architecture in Contemporary Poland”

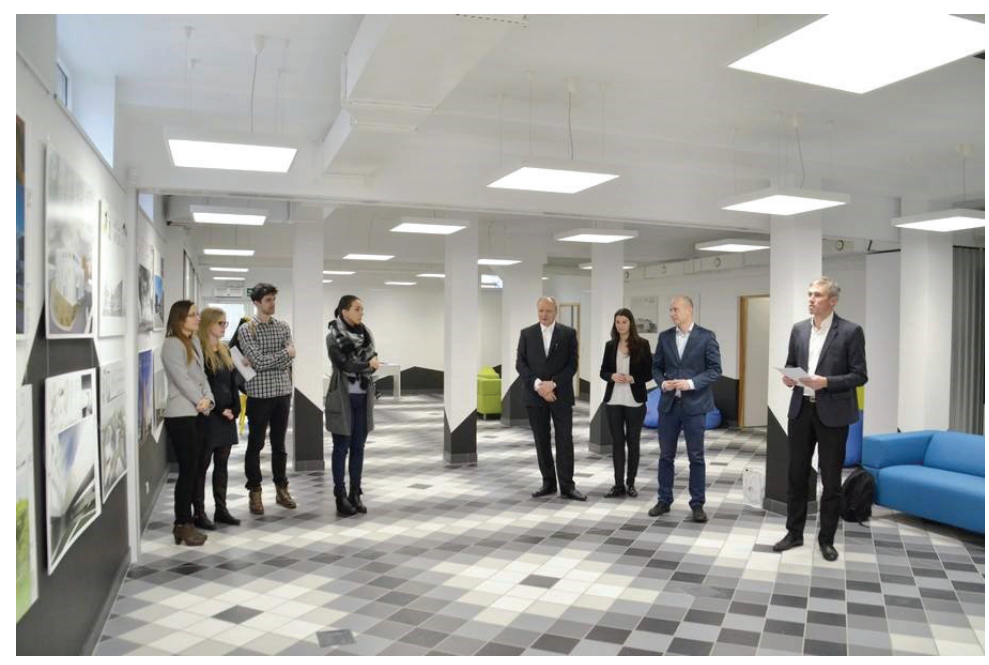

II. 5. Nagrodzeni studenci oraz dr hab. inż. arch. Kazimierz Butelski - kierownik Pracowni Architektury Społeczno-Usługowej A24, mgr inż. arch. Marta Łukasik - Pracownia A24, mgr Wojciech Biernat - kierownik Referatu Strategii i Rozwoju UMig Niepołomice, mgr inż. arch. Adam Twardowski zastępca burmistrza miasta i gminy, zdjęcie dzięki uprzejmości UMiG Niepołomice

III. 5. Awarded students and PhD DSc Eng. Arch. Kazimierz Butelski, Headmaster in Chair of Social and Public Building Design A24, M.Sc. Eng. Arch. Marta Łukasik A24, M.Sc. Wojciech Biernat - Head of the Department of Strategy and Development, UMiG Niepołomice, M.Sc. Adam TwardowskiDeputy Mayor of the Town and Commune, photo courtesy of UMiG Niepołomice 


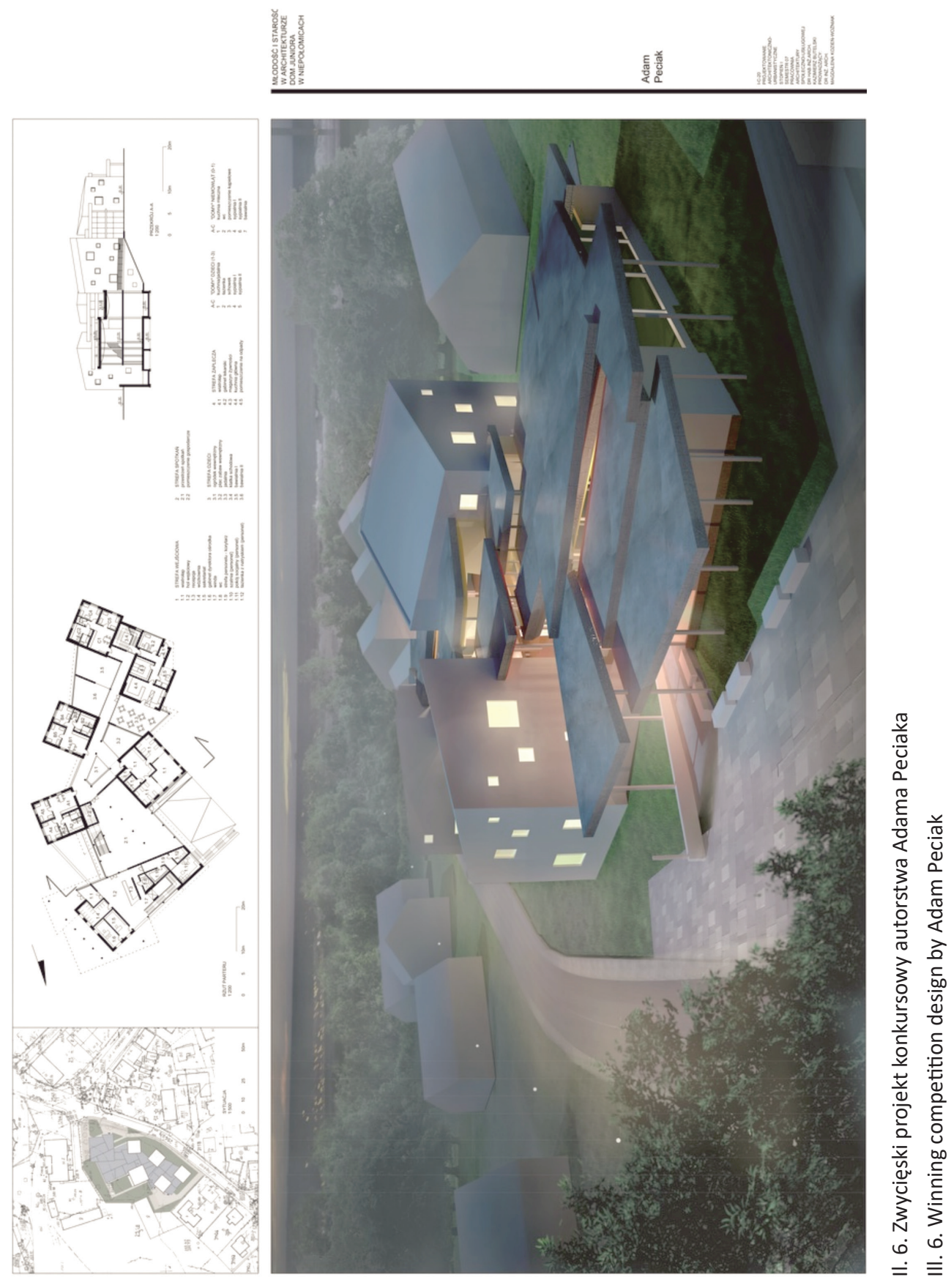




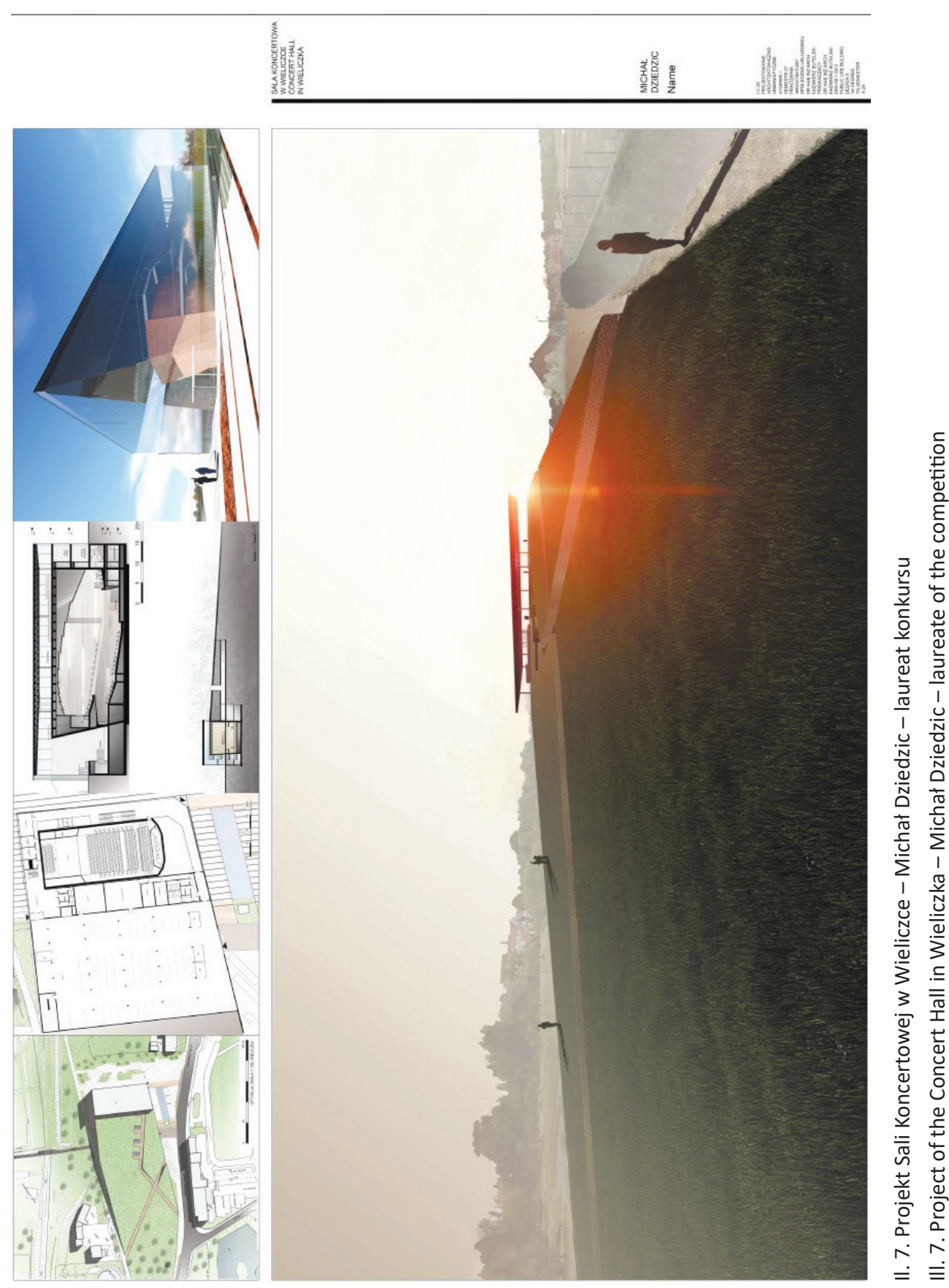




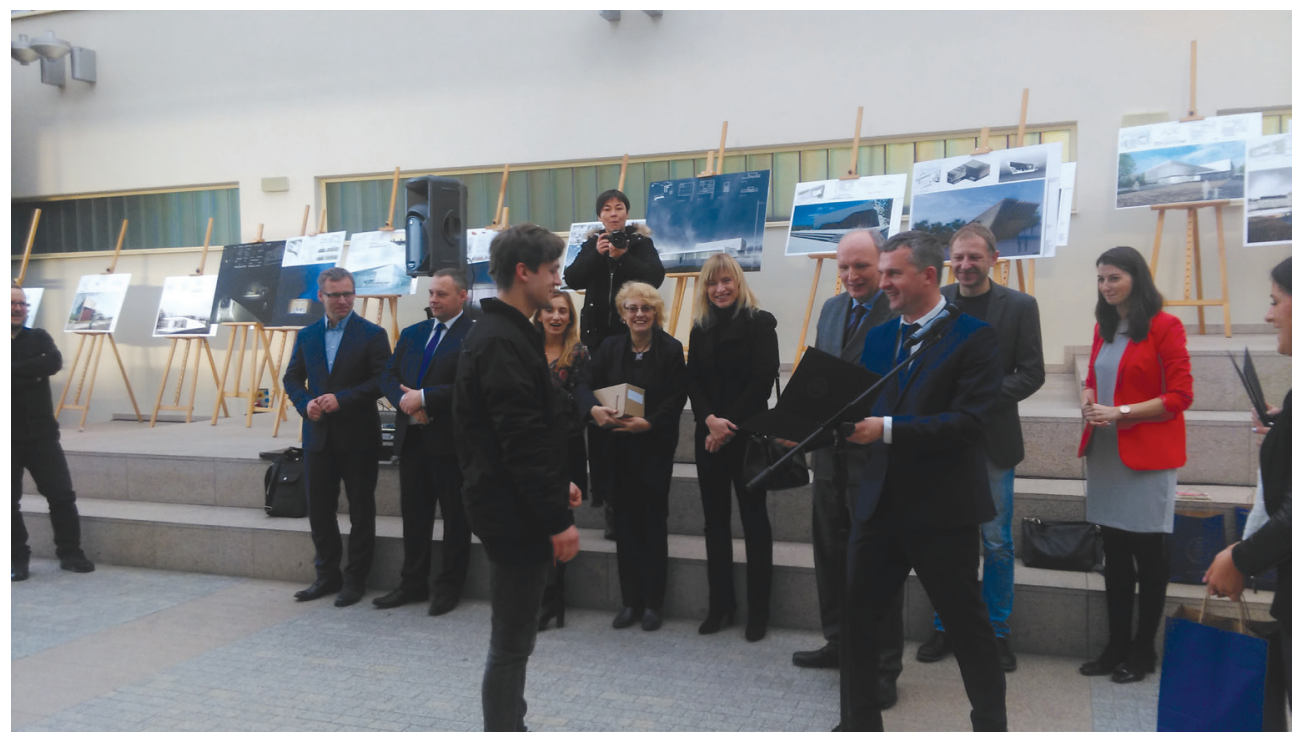

II. 8. Wernisaż wystawy oraz wręczenie nagród - „Solne Miasto” w Wieliczce, 5 grudnia 2016

III. 8. Exhibition opening and awarding ceremony - „Solne Miasto” in Wieliczka, 5th December 2016, photo courtesy of UMiG Wieliczka 


\section{PRZYPISY}

1 http://www.jhi.pl/psj/chasydyzm_polski.

2 Pierwotny budynek był drewniany, następny murowany został zniszczony przez Niemców w czasie okupacji. Obecna forma jest wynikiem jego odbudowy w latach 60. XX wieku.

3 Rabin chasydzki z ruchu Chabad-Lubawicz.

4 Za: http://www.wieliczka.eu/pl/201506/0/projekty-strategiczne.html.

\section{BIBLIOGRAFIA}

http://www.jhi.pl/psj/chasydyzm_polski (dostęp: 22.05.2017).

Chasydyzm - od herezji do ultraortodoksji. Hasidism - from heresy to ultra-orthodoxy, [w:] Czas chasydów. Time of the Hasidim, Kraków 2005, s. 11-41.

Chabad: pomiędzy mistykq a mesjanizmem, [w:] Światło i słońce. Studia z dziejów chasydyzmu, pod red. Michała Galasa, Kraków 2006, s. 129-145.

Chasydyzm czy chasydyzmy? Główne aspekty dziejów mistyki żydowskiej na ziemiach polskich, [w:] Żydzi w Lelowie. Obecność i ślady, pod red. Michała Galasa i Mirosława Skrzypczyka, Kraków 2006, 41-58.

Wiśniewski T., Bożnice Białostocczyzny, Białystok 1992.

Szafranowicz P., Środowiska terapeutyczne - nowe podejście do problematyki przestrzeni obiektów służby zdrowia, Gdańsk 2005.

Porębowicz S., O miejsce dla starego człowieka w nowo powstajqcych zespołach miejskich, „Szpitalnictwo Polskie”, t. VIII, 6, 1964, s. 282-287.

http://www.wieliczka.eu/pl/201506/0/projekty-strategiczne.html (dostęp: 26.05.2017).

Kamisiński T., Rubacha J., Pilch A., Badania struktur rozpraszających dźwięk dla potrzeb adaptacji akustycznej wnętrz - A study of sound scattering structures for the purposes of room acoustic enhancement, [w:] XVI Konferencja Inżynierii Akustycznej i Biomedycznej: Kraków-Zakopane, 30 marca - 3 kwietnia 2009 - XVI Conference on Acoustic and Biomedical Engineering, Kraków 2009, s. 18-19. 